\title{
Are saltflats suitable supplementary nesting habitats for Malaysian Plovers Charadrius peronii threatened by beach habitat loss in Thailand?
}

\author{
MAÏ YASUÉ, ALLISON PATTERSON and PHILIP DEARDEN
}

\section{Summary}

Resort development and coastal beach erosion have led to declines in beach breeding habitat for the near-threatened Malaysian Plover (Charadrius peronii) in the Gulf of Thailand. Seminatural saltflats may provide supplementary nesting areas. We compared the environmental conditions, incubation behaviour and nesting success of plovers breeding on sandy beaches and saltflats in Thailand. In total we monitored 21 and nine nesting attempts in 2004 (beaches and saltflats, respectively) and 26 and 22 nesting attempts in 2005. Despite higher air temperatures in the saltflats $(P<0.0001)$, we detected no significant differences in nest attendance $(P=0.542$ and $P=0.885$ for 2004 and 2005 , respectively), number of incubator changes between parents $(P$ $=0.776$ and $P=0.823)$ or number of parental nest departures $(P=0.087$ and $P=0.712)$ during 120 incubation observations on 55 nests. There was also no difference in hatching success between beaches in 2004 (beach $=0.65$, saltflat $=0.55 ; P=0.692, n=26$ ) and 2005 (beach $=$ 0.46 , saltflat $=0.35 ; P=0.539, n=41$ ). These results suggest that saltflats may provide nesting habitat for Malaysian Plovers and could help enhance overall hatching success rates by reducing nesting densities on beaches. Although there are few remaining intact saltflats in coastal Thailand, there are currently vast areas of abandoned tiger prawn aquaculture ponds that could be rehabilitated into saltflats at relatively low cost. Given the large area of disused aquaculture ponds throughout Thailand and South-East Asia and the substantial human pressure on coastal habitats, there could be considerable conservation benefits to the restoration of aquaculture ponds.

\section{Introduction}

Sandy tropical beaches are important breeding and foraging areas for waterbirds. However, these habitats are threatened by resort development, road construction, coastal erosion, sea-level rise and human disturbance (Burger et al. 1997, Brown and McLachlan 2002, Yasué and Dearden 2006b). The population impacts of such habitat changes depend on whether there are alternative areas waterbirds can use and attain similar levels of survivorship and fecundity (Elphick 2000, Smart and Gill 2003). Research relating the values of alternative habitats to wildlife, along with the socio-economic costs of protecting these areas, can help resource managers partition conservation efforts between different types of habitats efficiently (Bernstein et al. 1991).

Malaysian Plovers (Charadrius peronii) are a Red-listed species affected by habitat degradation in beach breeding habitats throughout their range in South-East Asia (Baillie et al. 2004, Yasué and Dearden 2006b). In Thailand, coastal development and beach erosion have reduced habitat availability in the main breeding habitats in Petchburi and Prachuap Khiri Khan 
provinces on the east coast of Thailand (Nutalaya 2006, Yasué and Dearden 2006b). At present there is little government support to conserve sandy beach habitat for wildlife because of the tremendous economic importance of beach tourism in Thailand. Consequently many more beach habitats will probably be lost to commercial development as the Thai economy continues to improve and domestic tourism expands.

A previous study of Malaysian Plovers suggested that pairs in areas of high conspecific nest density had lower hatching success (Yasué and Dearden 2006b). If Malaysian Plover populations are limited by breeding success and habitat availability, seasonal, semi-natural saltflats may provide supplementary nesting areas which could reduce beach nesting densities and buffer the population impacts of habitat loss. These saltflats are formed by natural tidal inundation as well as anthropogenic dyking or canalization for aquaculture, mangrove reforestation and the creation of salt evaporation ponds. They are sparsely vegetated with mangrove and halophyte vegetation and, because they are only inundated during high-level high tides that occur during the winter, they provide supratidal foraging habitat for a range of wintering waterbirds during low and mid-tides (Velasquez and Hockey 1992, Weber and Haig 1997) and also breeding habitats for species such as Malaysian Plovers, Black-winged Stilts Himantopus himantopus, Little Terns Sterna albifrons and Red-wattled Lapwings Vanellus indicus during the summer when maximum high tides are lower (P. Round, unpubl. data).

To date, apart from anecdotal or census information, few studies have examined the breeding ecology of the Malaysian Plover (Yasué and Dearden 2006a, 2006b, 2006c, 2007) and limited research has been conducted on the habitat use of tropical saltflats by waders in general (Gorman and Haig 2002). In Khao Sam Roi Yod National Park (KSRY), Malaysian Plovers nest either on coastal sandy beaches that are immediately adjacent to tidal mudflats, or on saltflats. Saltflats are beside the sandy beaches (i.e. beaches are located between saltflats and mudflats) and both habitats are available throughout the entire breeding season. Consequently KSRY provides an excellent opportunity to assess the relative habitat value of saltflats.

In this study we compared environmental factors that affect behaviour and breeding success in waders. These factors include thermal stress (Brown and Downs 2003, Amat and Masero 2004a), predation risk (Brook and Tanacredi 2002, Amat and Masero 2004b), flood risk (Round et al. 2004) and human disturbance or trampling (Weston 2000, Ruhlen et al. 2003). Although foraging quality is another factor influencing habitat selection in waders (Ens et al. 1992), this was not examined in our study because both beach and saltflat adults and chicks fed together on the mudflats in front of the beaches.

Thermal regulation of clutches is a key factor influencing avian breeding success (White and Kinney 1974). In tropical environments, waders must shade eggs to prevent overheating (Ward 1990). Air temperatures may be greater on saltflats than beaches because a 5-40 $\mathrm{m}$ wide vegetated border between the beaches and saltflats prevents cool oceanic breezes from reaching the saltflats. Adults in hot environments may spend more time attending nests because of the greater need to shade eggs (Carey 1980, Weathers and Sullivan 1981, Ward 1990). Also, birds may alternate incubation duties more frequently between mates during hot weather to reduce excessive heat stress on adults (Ward 1990). There may be higher attendance, higher rates of nest abandonment and lower hatching success on saltflats because unattended nests on saltflats may quickly reach lethal temperatures (Dunning and Bowers 1990, Conway and Martin 2000, Amat and Masero 2004b).

The vulnerability of nests to predators may also differ between the two habitats. The extent of vegetation cover and proximity to water can influence predator density and a nest's vulnerability to predators (Page et al. 1985, Burger 1987, Pampush and Anthony 1993, Wolff et al. 1999). There may be higher densities of marine predators (e.g. crabs) on beaches and higher densities of mangrove predators (e.g. snakes and mongooses) on saltflats. The dykes or Acacia and mangrove bushes that surround most saltflats may lower visibility and reduce an incubating adult's ability see approaching predators. Moreover, nests on saltflats may also be more vulnerable to predators because the vegetation between saltflats and beaches prevents adults that are feeding on the 
mudflat from detecting predators approaching the nest. In contrast, due to the open structure of the beach, beach-breeding plovers can simultaneously feed and watch for predators. When predators are detected, Charadrius plovers conduct distraction displays or attack predators to reduce predation rates (Gochfeld 1984, Yasué and Dearden 2006a).

Nests located on narrow strips of sandy beach are vulnerable to tidal inundation during very high level tides or storm surges (Eyler et al. 1999, Round et al. 2004). Saltflat nests are less vulnerable to floods because of the slightly elevated vegetated area between beaches and saltflats. Although the saltflats occasionally flood at very high tides in the winter, during the breeding season they were never inundated by tides at KSRY (M. Yasué, unpubl. data).

Anthropogenic disturbance could also differ between habitats. Beaches are likely to be favoured transportation routes for people, dogs and cattle because they are more accessible, cooler and less vegetated. As a result, beach-nesting plovers may spend more time responding to anthropogenic disturbances and suffer greater clutch mortality due to direct trampling (Melvin et al. 1994, Ruhlen et al. 2003).

In this study we compared environmental conditions as well as the behaviour and breeding success of Malaysian Plovers on sandy beaches and saltflats to evaluate whether saltflats could provide suitable supplementary nesting habitats and help to reduce the population impacts of beach habitat loss.

\section{Methods}

\section{Study area}

All data were collected within a $5 \mathrm{~km}$ stretch of beaches in Khao Sam Roi Yod National Park $\left(99^{\circ} 58^{\prime} \mathrm{N}, 12^{\circ} \mathrm{O} 6^{\prime} \mathrm{E}\right)$ in Prachuap Khiri Khan province from 25 April to $25 \mathrm{July}$ in 2004 and 2005. Both beach and saltflat plovers defended 100-300 $\mathrm{m}$ long linear territories that consisted of a mudflat (20-400 m exposed at low tide) as well as a $4-80 \mathrm{~m}$ wide beach section or saltflat nesting area. Both beach- and saltflat-nesting pairs fed on the mudflats and hid chicks in the vegetated area next to the beach or on saltflats when there were disturbances on the beach. The vegetated area between beaches and saltflats had short shrubby dune vegetation, mangroves, Acacia bushes or Casuarina trees. Vegetation covered $1-30 \%$ of the land surface on the saltmarsh and the size of individual saltflats (as demarcated by dykes and vegetation) ranged from 2,000 $\mathrm{m}^{2}$ to 350,000 $\mathrm{m}^{2}$. In contrast to the porous sandy beaches, the substrate of saltflats was hard, consolidated mud with a surface layer of evaporated salt.

\section{Nest monitoring}

We found nests by searching in areas where pairs were frequently observed or by watching birds return to nests. We also floated eggs in water and measured the diameter of eggs above the surface of water in order to detect embryo mortality, estimating laying date and hatching date based on a 30-day incubation period (Westerkov 1950, Powell 2001, Yasué and Dearden 2006c). We checked the nests every 3-5 days to determine nest survival or cause of failure. Checks were conducted more frequently close to hatching date because of the high mortality rates of very young chicks. If any clutches less than 25 days old disappeared between checks and there was no sign of inundation (destroyed nest structure, tidal debris at nest) or trampling (crushed nest structure and eggs, tracks of vehicles and footprints), we assumed that eggs had been depredated. This was a reasonable assumption because at our study area local people did not collect eggs for consumption. During nest checks we re-sighted adults to ensure that they were still present and to discriminate between desertion and predation as cause of failure (Yasué and Dearden 2006b). Detailed observations of adults and chicks helped us to determine whether nests had failed or succeeded. Adults with failed nests roosted or fed in pairs on the mudflat, whereas adults with young chicks conducted conspicuous distraction displays when we approached the nest-site. We 
captured and individually colour-banded chicks within 2 weeks of hatching and returned to the nesting territories weekly to assess chick survival up to 30 days. Assessing fledgling success was not difficult because plovers did not move more than $300 \mathrm{~m}$ from their nest-sites. Family groups could be identified because at least one of the chicks or adults was individually colour-banded. The majority of adults were caught and banded either during the preceding winter, summer or on nests using noose mats or funnel traps (number of banded adults and chicks: 72 and 94, respectively; Mehl et al. 2003).

In total we monitored 21 and nine nesting attempts in 2004 (beaches and saltflats, respectively) and 26 and 22 nesting attempts in 2005 .

\section{Nest observations}

We recorded shaded air temperature using a mercury thermometer at a height of $20 \mathrm{~cm}$ above the beaches and saltflats several times during the day throughout the course of the study.

We continuously watched incubating plovers using a $15-45 \times$ spotting scope or $10 \times 50$ binoculars for $1-2$ hours (mean length $=[$ mean $\pm \mathrm{SE}]=81 \pm 3.2 \mathrm{~min}$ ) from either a hide or a seated position on the mudflat or elevated position within saltflats located more than $100 \mathrm{~m}$ from the plovers. One hundred and twenty incubation watches were conducted on 55 different nests between April and July in 2004 and 2005. No incubation watches were conducted on the same pair on the same day.

Malaysian Plovers are biparental incubators and the male and female alternate incubation duties throughout the day (Yasué and Dearden 2007b). During incubation watches we recorded the time when each of the parents arrived or left the nest. Attendance was the proportion of time the clutches were incubated by either bird. We also recorded the total number of times the sexes alternated incubation duties and the total number of times either adult left the nest during incubation watches. We standardized values to hourly values.

For nests in which we conducted replicate observations, we calculated mean values for the three incubation behavioural variables and used aggregated values in statistical analysis. However, we considered multiple nests of the same pair as independent. This is because incubation behaviour is influenced by several factors such as nest location and microclimate, weather and time of year that vary between different nesting attempts of the same pair (Carey 1980, Amat and Masero 2004b). The variability in incubation behaviour that results from these factors is likely to be more important than variability that occurs between individual pairs. However, as some pairs nested on both saltflats and beaches in a single year, this may have made our results less likely to detect differences between the habitats.

\section{Vulnerability to predators and flooding}

By crouching to the height of a Malaysian Plover, we visually estimated the percentage of the circumference around the nest where an incubating plover would be able to detect an approaching predator $20 \mathrm{~m}$ away. Percentage visibility from nests affects both clutch survival and the predation risk on adults incubating clutches (Wiebe and Martin 1998, Amat and Masero 2004 b). Plovers rely largely on sight to watch for predators and early detection of predators allows adults to distract predators away from nests to increase hatching success (Amat and Masero 2004b). We also measured the distance from the nest to the nearest contiguous vegetated area (either the start of the vegetation line adjacent to the beach, or the closest vegetated boundary of the saltflats). This is because predators such as raptors can use vegetation cover to approach and ambush waders (Wolff et al. 1999, Dekker and Ydenberg 2004). We also measured the distance from the nest to the nearest high-tide line, based on the location of the strandline and the presence of tidal debris on the beach, in order to assess flood risk. For this analysis, if a single pair of plovers nested more than once on the beach or saltflat in a year, we used mean values of the different nesting attempts in each of the two habitats. 


\section{Disturbance responses}

We quantified anthropogenic (people, dogs, cattle and vehicles) and natural (predators such as raptors, mammals and crabs, false alarms) disturbance responses by recording the type of disturbance stimuli and the length of time of the adults' response during incubation watches. Birds were categorized as disturbed if they were exhibiting anti-predatory behaviour such as neck-outstretched vigilance posture, flushing onto the mudflat, 'rat-running', chasing intruders, calling to distract predators, false brooding or crouching (Gochfeld 1984). The amount of time birds responded to disturbances was standardized to minutes per hour. Occasionally we were not able to detect the stimuli causing the disturbance response of birds. These disturbances were categorized as 'natural disturbances' because anthropogenic stimuli such as cars, people or dogs are unlikely to be missed, whereas natural disturbance stimuli such as cryptic predators or false alarms may be much harder to detect. Frequently birds responded to the rapid flights of other waders or to fish-eating raptors such as Osprey Pandion haliaetus.

The disturbance measure we used in this study was based on the response of the birds, rather than on the frequency of potential disturbance stimuli. Comparing disturbance stimuli was difficult for this study (e.g. the number of people or predators that approach the nest per hour) because the ability of plovers to detect predators probably varied between the two habitats. Moreover, we were able to see very few predators during our study and it is unlikely that we would be able to detect predators in a standardized way without relying on cues from the behaviour of the birds.

For nests in which we conducted replicate observations, we calculated mean values for the anthropogenic and natural disturbance rates and used aggregated values for statistical analysis. We did not pool data between different nesting attempts of the same pair because there is likely to be greater variability between nesting attempts due to seasonal changes in predators (DeCandido et al. 2004) or human disturbance rates and weather rather than between individual pairs.

\section{Statistical analysis}

We used a paired $t$-test to compare the temperature between the beach and salt ponds that were taken in the same hour and within $500 \mathrm{~m}$. If multiple measurements were taken in each habitat during an hour we compared mean values.

For all comparisons of habitat characteristics, behaviours and disturbance rates between beach and saltflats we used a Mann-Whitney Test of Independent Samples because data could not be normalized using standard data transformations. We conducted analysis for the two years separately to reduce pseudoreplication because several pairs nested at our site in both years.

We calculated hatching success based on the daily exposure method (Mayfield 1961). A nest that hatched at least one chick was considered 'successful' in this study. If a single pair laid more than one clutch on a beach or saltflat site in the one year, we randomly sampled one of these nests for the Mayfield calculations. Consequently, although a total of 37 and 52 nests were monitored in the two years, our Mayfield nest probabilities were based on 26 and 41 nests. We used a two-sided Fisher's Exact Test to compare hatching success between the two habitats (Dow 1978, Johnson 1979) because this is more robust to low sample sizes than the chi-squared test.

All error estimates presented are standard errors.

\section{Results}

Although temperature was slightly higher on the saltflats $\left(34.0 \pm 0.3{ }^{\circ} \mathrm{C}\right)$ than on the beaches $\left(32.2 \pm 0.3^{\circ} \mathrm{C}\right.$ ) (paired $t$-test: $t=-8.7, n=71, P<0.0001$ ), there was no significant difference in the number of parental changes in incubation duties, number of times an adult left the clutch during an incubation observation, or nest attendance (Table 1 ). 
Table 1 . Results of Mann-Whitney tests comparing incubation behaviour for beach and saltflat breeding habitats.

\begin{tabular}{lllll}
\hline & Year & $Z$ & $P$ & Pooled mean \\
\hline Nest attendance (proportion) & 2004 & -0.9 & 0.391 & $0.6 \pm 0.1$ \\
& 2005 & -0.2 & 0.885 & $0.6 \pm 0.1$ \\
Number of incubator changes $\left(\mathrm{h}^{-1}\right)$ & 2004 & -0.3 & 0.776 & $0.8 \pm 0.2$ \\
& 2005 & -0.2 & 0.823 & $0.9 \pm 0.2$ \\
Number of adult clutch departures $\left(\mathrm{h}^{-1}\right)$ & 2004 & -1.7 & 0.087 & $1.6 \pm 0.3$ \\
& 2005 & -0.4 & 0.712 & $1.9 \pm 0.2$ \\
\hline
\end{tabular}

Sample sizes for beaches and saltflats were $n_{\mathrm{BE}}=15$ and $n_{\mathrm{SF}}=8$ for 2004 and $n_{\mathrm{BE}}=27$ and $n_{\mathrm{SF}}=19$ for 2005

Saltflats were significantly further from the high-tide line and from contiguous vegetation than the beach nests. However, there was no significant difference in percentage visibility (Table 2).

Anthropogenic and natural disturbance rates were generally very low for both habitat types (pooled anthropogenic and natural disturbance rates 2004: beach, $3.6 \pm 0.8 \mathrm{~min} \mathrm{~h}^{-1}$; saltflat, 2.2 $\pm 0.3 \operatorname{min~h}^{-1}$; 2005: beach $0.85 \pm 0.3 \operatorname{min~h}^{-1}$; saltflat, $0.33 \pm 0.3 \operatorname{min~}^{-1}$ ). Anthropogenic disturbance rates were higher during incubation watches on beach nests in $2005(z=-2.4, P=$ 0.019, $n_{\mathrm{BE}}=33, n_{\mathrm{SF}}=22$; beach, $0.7 \pm 0.3 \mathrm{~min} \mathrm{~h}^{-1}$; saltflat, $0.3 \pm 0.3 \mathrm{~min}^{-1}$ ) but not in 2004 $\left(z=-0.35, P=0.750, n_{\mathrm{BE}}=20, n_{\mathrm{SF}}=10\right.$; pooled mean $\left.=2.0 \pm 0.62 \mathrm{~min}^{-1}\right)$. The main sources of anthropogenic disturbances were local fishermen, cattle or motor vehicles. We only detected two disturbance responses caused by natural predators on saltflats. Consequently, we did not conduct tests to compare natural disturbance rates between the two habitat types.

Plovers responded to humans, dogs and mongooses in the same way. Beach plovers would sneak away from the nest and run onto the mudflat or $20-30 \mathrm{~m}$ away from the nest along the beach. Then they would approach or circle the disturber, call, feign injury or false brood (Gochfeld 1984, Montgomerie and Weatherhead 1988). When the disturber began to walk away, plovers continued to follow the disturber for $30-100 \mathrm{~m}$ from the nest. Eventually the plovers would run back out to the mudflat directly in front of the nest, and then discreetly and quickly return directly to the nest. Saltflat birds responded to people in a similar way. If the people were on the beaches adjacent to their nesting territory, saltflat birds would frequently fly out onto the mudflat or beaches to conduct distraction displays. If people walked along the saltflat, then birds tended to display on the saltflat and try to lead the person onto the mudflat or beach. When approached by cattle or motor vehicles, plovers tended to remain either on the nest or stay on the nest until the disturber had approached within 5-10 $\mathrm{m}$ of the nest. Then beach plovers would run quickly onto the mudflat directly in front of the nest before returning to the nest. Saltflat plovers did not fly to the mudflats, but rather ran 30-50 m away from the nest and conducted

Table 2. Results of Mann-Whitney comparisons of conditions contributing to predation and flood risk for beach and saltflat breeding habitats.

\begin{tabular}{lccccc}
\hline & \multicolumn{2}{c}{ Beach } & Saltflat & $z$ & $P$ \\
\hline Visibility (\%) & 2004 & \multicolumn{2}{c}{$52.8 \pm 3.5$} & -1.0 & 0.312 \\
& 2005 & \multicolumn{2}{c}{$50.3 \pm 3.2$} & -0.6 & 0.588 \\
Distance to vegetation (m) & 2004 & $6.9 \pm 1.1 \quad 13.3 \pm 2.8$ & -2.0 & $\mathbf{0 . 0 4 5}$ \\
& 2005 & $9.8 \pm 4.5$ & $18.6 \pm 7.2$ & -2.1 & $\mathbf{0 . 0 3 6}$ \\
Distance to tide line (m) & 2004 & $6.7 \pm 0.9$ & $32.2 \pm 9.5$ & -2.6 & $\mathbf{0 . 0 0 8}$ \\
& 2005 & $10.2 \pm 1.6$ & $37.5 \pm 3.8$ & -4.7 & $<\mathbf{0 . 0 0 1}$ \\
\hline
\end{tabular}

$n_{\mathrm{BE}}=17$ and $n_{\mathrm{SF}}=9$ for 2004 and $n_{\mathrm{BE}}=23$ and $n_{\mathrm{SF}}=14$ for 2005 .

Significant results are in bold. 
distraction displays within the saltflat environment. When ghost crabs (Ocypode spp.) approached the nest on beaches, plovers would chase the crab, extend and bat their wings, or feign injury within $\mathrm{I} \mathrm{m}$ of the crab. When responding to a peregrine falcon or a false alarm caused by another bird, plovers would remain on the nest, crouch and look up (Gochfeld 1984).

\section{Breeding success and re-nesting behaviour}

There was no significant difference in hatching success between the two habitats in 2004 (Fisher's Exact Test, $n=26, P=0.692)$ or $2005(n=41, P=0.539$; Table 3$)$. We could not use a Pearson's chi-squared test to assess whether the number of nests that failed due to flooding, desertion, or predation varied between the two habitats due to low cell counts in contingency tables (Dow 1978) and so we present a descriptive graph of the causes of nest failure in the two years.

Nine nests failed on the beaches and none on the saltflats due to tidal inundation (Figure I). Tidal flood risk was higher on beaches than saltflats because, in our study area, beaches were

Table 3. Mayfield nest success calculated from nest daily survival rates.

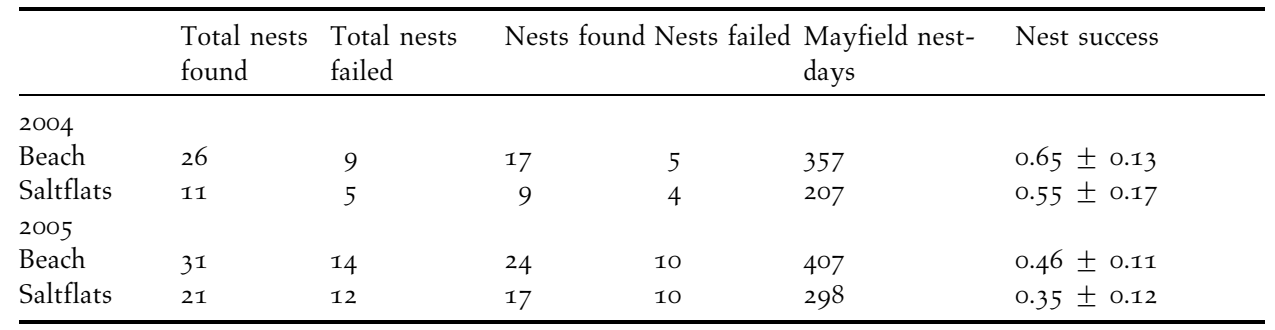

Total nests found and failed include multiple nests from the same pair in the same habitat (columns 1 and 2 from left). Nest success was calculated based on nest survival by sampling one of the nests of the same pair in each habitat (columns 3 and 4 ). Nests succeeded if they hatched at least one chick.

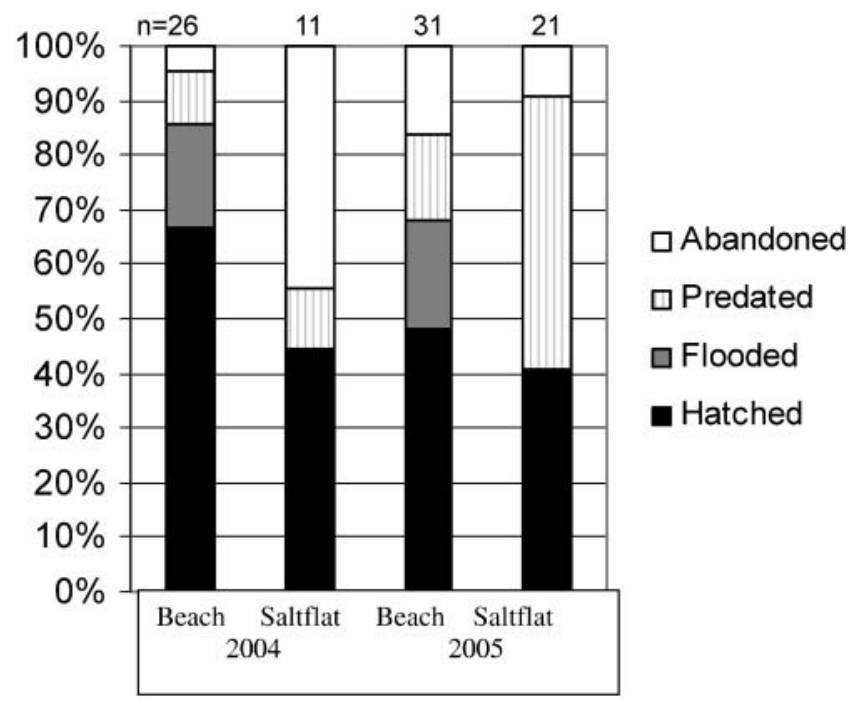

Figure 1. Cause of nest failure for beach and saltflat nests in 2004 (left bars) and 2005 (right bars). Sample sizes for each of the bars are denoted above each column. 
between the saltflats and the tidal edge so any tide inundating the saltflat would also inundate the beach habitat. The one saltflat nest that did fail because of flooding did so during a period of intense rainfall in May of 2004 ( $90 \mathrm{~mm}$ in 2 days), the greatest rainfall in a 24 hour period between May and August since at least 1994 according to a national meteorological weather station in Hua Hin city, $99^{\circ} 57^{\prime} \mathrm{N} 12^{\circ} 36^{\prime} \mathrm{E}$ ). Water could not penetrate through the surface layer of the saltflat and pooled on it. This type of flooding is unlikely to be significant source or mortality in most years because of the rarity of such intense rainfall during the breeding season. No beach nests were flooded by rain and no other saltflat nests were flooded, despite moderate rain in 2004 and 2005 ( $15-20 \mathrm{~mm}$ in 1 day).

For most of the suspected depredated nests, entire clutches disappeared between checks and we were unable to identify the predator (Yasué and Dearden 2006b). We saw Small Indian Mongoose Herpestes javanicus on three occasions (twice on beaches, once on saltflats) in our study area and terns and Malaysian Plovers exhibited intense anti-predation responses. On six occasions we observed Ocypode ghost crabs apparently attempt to predate clutches on beaches. Adult plovers responded by attacking and chasing crabs. Corvids, gulls or other known diurnal avian Charadrius plover nest predators (Mayer and Ryan 1991, Lauro and Tanagredi 2002) were never observed searching for nests during the course of our study.

There were approximately 1oo pairs of Little Terns Sterna albifrons sharing the saltflat with Malaysian Plovers in KSRY. In 2005 there were three nest checks in which entire clusters of five to 20 Little Tern and a few Malaysian Plover nests (within $1 \mathrm{~km}$ of each other) were found to be depredated on the saltflats. Predation rates appeared to be marginally higher on the saltflats in 2005 (Figure 1).

After very low success rates at the start of the 2005 breeding season, a significant proportion $(58 \%)$ of the birds re-nested after failed breeding attempts. In 2005, seven of the 12 pairs that nested on saltflats, also nested at least once in the beach habitats. In 2004, three out of four of the pairs that re-nested, nested in both habitat types in the same year.

We could not compare fledging success rates (the proportion of hatched chicks that fledged) between the two habitats statistically in this study because of insufficient sample size. However, we believe that it was more important to focus on differences in nest success because both beachand saltflat-nesting plovers reared chicks on mudflats, beaches and saltflats. In 2004, 81\% $(n=$ 16) and $80 \%(n=5)$ of nests that hatched chicks, fledged chicks on the beach and saltflats, respectively, while in $200510 \%(n=21)$ and $17 \%(n=6)$ of the successful nests fledged chicks in the two habitats. It appeared that fledging success rates differed more between years rather than between nesting-habitats.

\section{Discussion}

\section{Saltflats as supplementary breeding habitats}

The results suggest that saltflats may provide suitable nesting habitat for Malaysian Plovers. Contrary to our predictions, there was no evidence indicating that thermal stress or predation risk was greater for birds breeding on saltflats. Environmental conditions on saltflats did not differ from beaches enough to affect Malaysian Plover breeding behaviour or hatching success.

In comparison with most other beaches in the Gulf of Thailand, disturbance rates were very low at KSRY and there was no evidence of direct trampling of eggs by people in our study area. We did find trampled nests in concurrent studies on other beaches in the Gulf of Thailand (Yasué and Dearden 2006b). Human disturbance on beaches is thought to limit the size of breeding populations of Malaysian Plovers (Baillie et al. 2004, Yasué and Dearden 2006b) and other related Charadrius plovers (Flemming et al. 1988, Ruhlen et al. 2003, Weston and Elgar 2005). Disturbance may be a more important difference between these two habitat types on beaches used more by tourists and the relative importance of saltflats to Malaysian Plover conservation may be greater in other coastal areas of Thailand. 
Previous research on Charadrius plovers demonstrated substantial annual variability in breeding success due to changes in environmental or ecological conditions (Lauro and Tanagredi 2002, Wallander and Andersson 2003). Annual variability in maximum temperatures, beach morphology, maximum water levels and flood-risk, or the presence of a highly effective wideranging predator in one of the habitats, could influence relative nesting success on sandy beaches and saltflats (Burger 1987, Koenen et al. 1996). For these reasons, more studies over several years would be necessary to evaluate the generality of these results.

Based on site visits to beaches along both eastern and western coasts of Thailand, and interviews with local bird-watchers and Thai academics (M. Yasué, unpubl. data), KSRY National Park had one of the highest densities of Malaysian Plovers in Thailand. This park may be favoured by plovers because it is one of the few areas where semi-natural saltflats still exist next to beaches and have not been replaced by roads, housing or tourism development. At KSRY both beaches and saltflats are available and plovers can adjust habitat choice depending on current environmental conditions such as maximum water height or predation risk (Amat and Masero 2004b). The ability to select different habitat types within a breeding territory may be particularly important for Malaysian Plovers because adults appeared to return to the same territory between years (M. Yasué, unpubl. data).

At present even pairs that nested on saltflats tended to spend most of the chick-rearing period on beaches. This is probably related to the proximity of the beaches to high-quality feeding areas on the mudflats. Thus Malaysian Plover populations may still depend on the protection of beach habitats. However, chicks sometimes fed on saltflats and other Charadrius plovers are known to feed in similar saltflat habitat (Warriner et al. 1986, Koenen et al. 1996, Masero et al. 2000). Habitat management on saltflats and the removal of some of the dykes or erosion-prevention structures that have been created for aquaculture or salt-production ponds in the past, may improve chick-rearing habitat quality and could allow chicks to be reared on saltflats.

At our site, it appeared that density-dependent reduction in breeding success occurred during the nesting stage (Yasué and Dearden 2006b) and it is possible that adults moved chicks onto the beaches because they are more able to tolerate higher densities when rearing chicks. In addition, plover densities on beaches during chick-rearing may still be below carrying capacity even including chicks from both beaches and saltflats because so many breeding attempts fail at the nesting stage. Additional studies on how saltflats are used by chicks, and how breeding densities during chick-rearing stages affect success, are necessary to assess whether saltflats can help buffer the population impacts of beach habitat loss.

\section{The potential to conserve saltflats and the restoration of aquaculture ponds}

Although there are currently few remaining semi-natural saltflats in the Gulf of Thailand, there may be greater potential for conservation of saltflats than beach habitats for two reasons. First, compared with sandy beaches, there is much greater government support for saltflat and wetland conservation in Thailand (Thongchai 1998, Erftemeijer and Lewis 1999, Stevenson et al. 1999). The recent enhanced awareness of the economic and ecological value of mangrove forests has led to saltflat restoration or reforestation initiatives (Macintosh 1996, Balmford et al. 2002). Secondly there may be lower financial costs for governments to conserve saltflats because there are currently vast areas of abandoned and naturalizing shrimp (Peneaus monodon) ponds in the Gulf of Thailand (Office of Environmental Policy and Planning (OEPP) 1994, Potaros 1995, Flaherty and Vandergeest 1998) and throughout Asia (Sammut and Mohan 1996, Yap 1997) that could be naturalized into saltflats (Stevenson et al. 1999). In the1980s, mangrove forests, natural saltflats and salt-evaporation ponds were rapidly converted into high-density industrial tiger prawn aquaculture ponds (Parr et al. 1993). However, water pollution, environmental degradation and disease lead to very high prawn mortality rates and proprietors generally abandoned ponds after 3-7 years of use to seek out new areas to construct ponds (Enright 1995). 
The majority of the coast in KSRY is dominated by aquaculture ponds of which $70-80 \%$ are no longer in use (Parr et al. 1993, Enright 1995, Stevenson et al. 1999). With deep sloping banks preventing any tidal inundation and no vegetation, these disused aquaculture ponds provide none of the wildlife values of the former natural coastal habitats. Park managers or conservation organizations could rehabilitate these ponds into semi-natural saltflats to create habitat for plovers and other waterbirds to feed and rear chicks. Removing dykes and allowing partial tidal inundation would help increase invertebrate prey densities and promote natural regeneration of wetland vegetation (Elphick and Oring 1998). Restoration may have tremendous conservation value because KSRY is the only National Park in Thailand with a significant population of Malaysian Plovers. In addition to resident species, KSRY has one of the highest densities of migratory waders in the Gulf of Thailand and the saltflats at KSRY provide important supratidal foraging areas for these birds (M. Yasué, unpubl. data).

The ability of Malaysian Plovers to use abandoned shrimp ponds for both nesting and fledging habitat was demonstrated on one beach $15 \mathrm{~km}$ south of KSRY. In July 2004, after illegal aquaculture operations were closed, these ponds were partially drained and allowed to naturalize. In contrast to other aquaculture ponds in the region abandoned several years ago, these ponds still had permanent pools of water covering $5-15 \%$ of the total area and short shrubby vegetation. In 2005 two pairs of plovers nested and fledged chicks in these aquaculture ponds. Although adults still fed on the mudflats, chicks fed exclusively within the disused aquaculture ponds around the water pools.

Despite the potential for habitat rehabilitation of aquaculture ponds, the availability of these abandoned aquaculture ponds still depends precariously on the lack of alternative lucrative land uses. There were several new resorts built near aquaculture ponds in 2005 within Prachuap Khiri Khan and Petchburi provinces. Without effective protection and active habitat rehabilitation, it is likely that these disused aquaculture ponds will be quickly converted to houses, resorts or roads and lost as potential habitats for birds (Kontogeorgopoulos 2004). Furthermore, managers of protected area have become accustomed to viewing abandoned ponds purely as an environmental problem rather than as potential areas for biodiversity conservation. This research suggests that ponds also offer considerable potential to help augment breeding habitat for certain species if active management measures are taken to assist this process. Given the area covered by abandoned ponds in South-East Asia and other areas of the tropics, the cumulative effects of rehabilitation on conservation could be substantial.

\section{Acknowledgements}

The authors thank anonymous referees and Michael Weston for comments on previous drafts. Thanks also go to George Gale, Philip Round, Andrew Pierce and Dhirayut Chenvidhya in Bangkok; staff at Khao Sam Roi Yod National Park and the villagers of Bonok for equipment and logistical support; and field assistant Prathew Tonghom. M. Y. was supported by a PGS-D scholarship from NSERC, Canada and the research project was funded by a SSHRC, Canada research grant. This study was conducted with support from the National Parks Department of Thailand.

\section{References}

Amat, J. A. and Masero, J. A. (2004a) How Kentish plovers, Charadrius alexandrinus, cope with heat stress during incubation. Behav. Ecol. Sociobiol. 56: 26-33.
Amat, J. A. and Masero, J. A. (2004b) Predation risk on incubating adults constrains the choice of thermally favourable nest sites in a plover. Anim. Behav. 67: 293-300. 
Balmford, A., Bruner, A., Cooper, P., Costanza, R., Farber, S., Green, R. E., Jenkins, M., Jefferiss, P., Jessamy, V., Madden, J., Munro, K., Myers, N., Naeem, S., Paavola, J., Rayment, M., Rosendo, S., Roughgarden, J., Trumper, K. and Turner, R. K. (2002) Economic reasons for conserving wild nature. Science 297: 950-953.

Bernstein, C., Krebs, J. R. and Kacelnik, A. (1991) Distribution of birds amongst habitats: theory and relevance to conservation. Pp. $317-345$ in C. M. Perrins, J. D. Lebreton and G. J. M. Hirons, eds. Bird population studies: Relevance to conservation and management. Oxford: Oxford University Press.

Brown, A. C. and McLachlan, A. (2002) Sandy shore ecosystems and the threats facing them: some predictions for the year 2025. Environ. Conserv. 29: 62-77.

Brown, M. and Downs, C. T. (2003) The role of shading behaviour in the thermoregulation of breeding crowned plovers (Vanellus coronatus). J. Therm. Biol. 28: 51-58.

Burger, J. (1987) Physical and social determinants of nest-site selection in piping plover in New Jersey. Condor 89: 811-818.

Burger, J., Niles, L. and Clark, K. E. (1997) Importance of beach, mudflat and marsh habitat to migrant shorebirds on Delaware Bay. Biol. Conserv. 79: 283-292.

Carey, C. (1980) The ecology of avian incubation. Bioscience 30: 819-824.

Conway, C. J. and Martin, T. E. (2000) Effects of ambient temperature on avian incubation behavior. Behav. Ecol. 11: 178-188.

DeCandido, R., Nualsri, C., Allen, D. and Bildstein, K. L. (2004) Autumn 2003 raptor migration at Chumphon, Thailand: a globally significant raptor migration watch site in South-East Asia. Forktail 20: 41-46.

Dekker, D. and Ydenberg, R. C. (2004) Raptor predation on wintering Dunlins in relation to the tidal cycle. Condor 106: 415-419.

Dow, D. D. (1978) A test of significance for Mayfield's method of calculating nest success. Wilson Bull. 90: 291-295.

Dunning, J. B. J. and Bowers, R. K. Jr (1990) Lethal temperatures in ash-throated flycatcher nests located in metal fence poles. J. Field Ornithol. 61: 98-103.
Elphick, C. S. (2000) Functional equivalency between rice fields and seminatural wetland habitats. Conserv. Biol. 14: 181-191.

Elphick, C. S. and Oring, L. W. (1998) Winter management of Californian rice fields for waterbirds. J. Appl. Ecol. 35: 95-108.

Enright, J. (1995) Aquaculture degrades Khao Sam Roi Yod National Park. Coast. Manage. Trop. Asia 4: 24-25.

Ens, B. J., Kersten, M., Brenninkmeijer, A. and Hulscher, J. B. (1992) Territorial quality, parental effort and reproductive success of oystercatchers (Haematopus ostralegus). J. Anim. Ecol. 61: 703-715.

Erftemeijer, P. L. A. and Lewis, R. R. (1999) Planting mangroves on intertidal mudflat: habitat restoration or habitat conversion? Paper presented at the ECOTONE-VIII Seminar "Enhancing Coastal Ecosystem Restoration for the 21st Century". Ranong and Phuket, 23-28 May 1999.

Eyler, T. B., Erwin, R. M., Stotts, D. B. and Hatfield, J. S. (1999) Aspects of hatching success and chick survival in Gull-billed Terns in coastal Virginia. Waterbirds 22: 54-59.

Flaherty, M. and Vandergeest, P. (1998) "Low-salt" shrimp aquaculture in Thailand: Goodbye coastline, Hello Khon Kaen! Environ. Manage. 22: 817-830.

Flemming, S. P., Chiasson, R. D., Smith, P. C., Austin-Smith, P. J. and Bancroft, P. P. (1988) Piping plover status in Nova Scotia related to its reproductive and behavioural responses to human disturbance. J. Field Ornithol. 59: 321-330.

Gochfeld, M. (1984) Antipredator behaviour: aggressive and distraction displays of shorebirds. Pp. 289-377 in J. Burger and B. L. Olla, eds. Shorebirds: breeding behaviour and populations. Volume 5: Behaviour of marine animals: Current perspectives in research. New York: Plenum Press.

Gorman, L. R. and Haig, S. M. (2002) Distribution and abundance of Snowy Plovers in eastern North America, the Caribbean, and the Bahamas. J. Field Ornithol. 73: 38-52.

IUCN (2006) Summary statistics for globally threatened species. www.iucnredlist.org/. Last accessed 25 July 2007. 
Johnson, D. H. (1979) Estimating nest success: the Mayfield method and an alternative. Auk 96: 651-661.

Koenen, M. T., Leslie, D. M. Jr and Gregory, M. (1996) Habitat changes and success of artificial nests on an alkaline flat. Wilson Bull. 108: 292-301.

Kontogeorgopoulos, N. (2004) Ecotourism and mass tourism in Southern Thailand: spatial interdependence, structural connections, and staged authenticity. GeoJournal 61: $1-11$.

Lauro, B. and Tanagredi, J. (2002) An examination of predatory pressures on piping plovers nesting at Breezy Point, New York. Waterbirds 25: 401-409.

Macintosh, D. J. (1996) Mangroves and coastal aquaculture; doing something positive for the environment. Aquaculture Asia 1: 3-8.

Masero, J. A., Perez-Hurtado, A., Castro, M. and Arroyo, G. M. (2000) Complementary use of intertidal mudflats and adjacent salinas for foraging waders. Ardea 88: 177-191.

Mayer, P. M. and Ryan, M. R. (1991) Electric fences reduce predation on Piping Plover nests and chicks. Wildl. Soc. Bull. 19: 59-63.

Mayfield, H. F. (1961) Nesting success calculated from exposure. Wilson Bull. 73: 255-261.

Mehl, K. R., Drake, K. L., Page, G. W., Sanzenbacher, P. M., Haig, S. M. and Thompson, J. E. (2003) Capture of breeding and wintering shorebirds with leghold noose-mats. J. Field Ornithol. 74: 401-405.

Melvin, S. M., Hecht, A. and Griffin, C. R. (1994) Piping Plover mortalities caused by off-road vehicles on Atlantic Coast Beaches. Wildl. Soc. Bull. 22: 409-414.

Montgomerie, R. D. and Weatherhead, P. J. (1988) Risks and rewards of nest defence by parent birds. Q. Rev. Biol. 63: 167-187.

Nutalaya, P. (2006) Coastal erosion in the Gulf of Thailand. GeoJournal 38: 283-300.

Office of Environmental Policy and Planning (OEPP) (1994) The environmental management of coastal aquaculture: An assessment of shrimp culture in Samut Sakhon and Chantaburi provinces. Bangkok:
Network of Aquaculture Centres in AsiaPacific (NACA).

Page, G. W., Stenzel, L. E. and Ribic, C. A. (1985) Nest site selection and clutch predation in the Snowy Plover. Auk 102: 347-353.

Pampush, G. J. and Anthony, R. G. (1993) Nest success, habitat utilization and nestsite selection of long-billed curlews in the Columbia Basin, Oregon. Condor 95: 957-967.

Parr, J. W. K., Mahannop, N. and Charoensiri, V. (1993) Khao Sam Roi Yot: one of the world's most threatened parks. Oryx 27: 245-249.

Potaros, M. (1995) Country report on Thailand. Annex 11-16. Bangkok: Network of Aquaculture Centres in Asia and the Pacific.

Powell, A. N. (2001) Habitat characteristics and nest success of Snowy Plovers associated with California Least Tern colonies. Condor 103: 785-792.

Round, R. A., Erwin, R. M. and Porter, J. H. (2004) Nest-site selection and hatching success of waterbirds in coastal Virginia: some results of habitat manipulation. J. Field Ornithol. 75: 317-329.

Ruhlen, T. D., Abbott, S., Stenzel, L. E. and Page, G. W. (2003) Evidence that human disturbance reduces Snowy Plover chick survival. J. Field Ornithol. 74: 300-304.

Sammut, J. and Mohan, C. V. (1996) Processes and impacts of estuarine acidification: the Richmond River, NSW and Karnataka, India. Acid sulphate soils causes management, effects, rehabilitation, prevention? New South Wales: The Earth Sciences Foundation, Department of Geology and Geophysics, The University of Sydney.

Smart, J. and Gill, J. A. (2003) Non-intertidal habitat use by shorebirds: a reflection of inadequate intertidal resources? Biol. Conserv. 111: 359-369.

Stevenson, N. J., Lewis, R. R. and Burbridge, P. R. (1999) Disused shrimp ponds and mangrove rehabilitation. Pp. 277-297 in W. Streever, ed. An international perspective on wetland rehabilitation. Amsterdam: Kluwer Academic.

Thongchai, C. (1998) Mangrove forest situation of Thailand in the past 35 years 
(1961-1996). Bangkok: Forest Resources Assessment Division, Royal Forest Department.

Velasquez, C. R. and Hockey, P. A. R. (1992) The importance of supratidal foraging habitat for waders of a south temperate estuary. Ardea 80: 243-253.

Wallander, J. and Andersson, M. (2003) Reproductive tactics of the ringed plover Charadrius hiaticula. J. Avian Biol. 34: 259-266.

Ward, D. (1990) Incubation temperatures and behavior of crowned, black-winged, and lesser black-winged plovers. Auk 107: 10-17.

Warriner, J. S., Warriner, J. C., Page, G. W. and Stenzel, L. E. (1986) Mating system and reproductive success of a small population of polygamous Snowy Plovers. Wilson Bull. 98: 15-37.

Weathers, W. W. and Sullivan, K. A. (1981) Nest attentiveness and egg temperature in the Yellow-Eyed Junco. Condor 91: 628-633.

Weber, L. M. and Haig, S. M. (1997) Shorebird use of South Carolina managed and natural coastal wetlands. J. Wildl. Manage. 6o: 73-82.

Westerkov, K. (1950) Methods for determining the age of game bird eggs. J. Wildl. Manage. 14: 56-67.

Weston, M. A. (2000) The effect of human disturbance on the breeding biology of the Hooded Plover. PhD dissertation. University of Melbourne, Melbourne.

Weston, M. A. and Elgar, M. A. (2005) Disturbance to brood-rearing Hooded
Plover Thinornis rubricollis: responses and consequences. Bird Conserv. Int. 15: 193-209.

White, F. N. and Kinney, J. L. (1974) Avian incubation. Science 186: 107-115.

Wiebe, K. L. and Martin, K. (1998) Costs and benefits of nest cover for ptarmigan: changes within and between years. Anim. Behav. 56: 1137-1144.

Wolff, J. O., Fox, T., Skillen, R. R. and Wand, A. G. (1999) The effect of supplemental perch sites on avian predation and demography of vole populations. J. Zool. 4: 535-541.

Yap, W. G. (1997) Can the Philippines produce enough fish for the multitude? Aquaculture Asia 11: 32-38.

Yasué, M. and Dearden, P. (2006a) The effect of heat stress, predation risk and parental investment on Malaysian plover nest return times following a human disturbance. Biol. Cons. 132: 472-480.

Yasué, M. and Dearden, P. (2006b) The potential impact of tourism development on habitat availability and productivity of Malaysian plovers Charadrius peronii. J. Appl. Ecol. 43: 978-989.

Yasué, M. and Dearden, P. (2006c) Simultaneous biparental incubation of two nests by a pair of Malaysian plover Charadrius peronii. Wader Study Group Bull. 109: 121-122.

Yasué, M. and Dearden, P. (2007) Parental sex roles of Malaysian plovers during territory acquisition, incubation and chick-rearing. Journal of Ethology. Available online.

\section{MAÏ YASUÉ, ALLISON PATTERSON, PHILIP DEARDEN}

Marine Protected Areas Research Group, Department of Geography, University of Victoria, P. O. Box 3050, Victoria, BC, V8 $\mathrm{W}_{3} P_{5}$, Canada.

*Author for correspondence.e-mail: maiyasue@gmail.com 